\title{
Value change analysis of batik woodcraft in Krebet Tourism Village
}

\author{
Dyah Widiyastuti ${ }^{1, *}$, Heni Ermawati ${ }^{1}$, and Lilik Andriyani ${ }^{1}$ \\ ${ }^{1}$ Department of Geographic Development, Faculty of Geography, Universitas Gadjah Mada, Indonesia
}

\begin{abstract}
Krebet Village is one of the villages located in Bantul Regency, D.I Yogyakarta. As one of the centers of wooden batik industry, Krebet Tourism Village is not only a tourist destination but also has wooden batik products that become the leading commodity of the village. The profession as a wooden batik industry craftsman in Krebet Tourism Village becomes the main livelihood for most of the villagers even extends to the surrounding villages. Wooden batik production activities performed by craftsmen from the manufacture to marketing of wood batik, where the way this product marketing varies between craftsmen one and the other. This study aims to analyze the value chain activities and identify marketing distribution of wooden batik products from Krebet Tourism Village. The analysis used descriptive analysis from structured interview data to 46 wooden batik business owners in Krebet Tourism Village. The results show that the actors involved in the value chain are raw material suppliers, raw material distributors, wooden batik industries, product distributors and retailers. Differences in the value chain in some wooden batik workshops have an impact on the different ways of product marketing which further contributes to the pattern of distribution of wooden batik commodity and earnings turnover.
\end{abstract}

\section{Introduction}

In recent years, the value chain has become an important component in running a business. A value chain describes all the activities necessary to bring a product or service that begins with the concept, followed by a production process that processes raw materials into a product or service, to produce products that can be delivered to consumers [1-4]. The value chain can be an approach to see the interaction between different economic actors.

Bantul Regency Spatial Plan 2010-2030 determines the existing tourism designation area in Bantul Regency covering cultural, natural, and artificial tourism. Krebet located in Sendangsari Village, Pajangan District, Bantul is one of artificial tourism area in Bantul regency [5]. Based on the spatial layout of Bantul Regency, the village has been designated as Krebet Craft Village or currently better known as Krebet Tourism Village. Wooden batik craft becomes the main attraction of tourism from this village.

Value chain analysis is a fundamental analysis of the development of any business including wooden batik business. The value chain analysis of wooden batik products is systematically able to map the economic actors who participate in the production, distribution, marketing, and selling of products. Wooden handicraft products from Krebet Tourism Village also need the value chain analysis to be able to assess the current business as well as to see opportunities to increase the competitiveness of wooden batik products in the international market.
The purpose of this study are:

1. Analyzing the value chain of wooden batik products from Krebet Tourism Village

2. Identify the marketing distribution of wooden batik products from Krebet Tourism Village.

\section{Methods}

This study used secondary and primary data. Data collection was done through literature study, interview, and non-participant observation. Structured interviews conducted with questionnaires addressed to the owner of wooden batik business in Krebet Tourism Village. The descriptive analysis technique was conducted to describe the flow of value chain that occurred in the production process and to map the distribution pattern of marketing of wooden batik products from Krebet Tourism Village.

\section{Results and discussions}

Value chain analysis of wooden batik products as a result of the creativity of Krebet people in making wooden batik, in the end, led to a center of wooden batik industry continues to grow. Various kinds of batik motifs such as parangbarong motif, kawung, parangrusak, garuda, sidorahayu, and sidomukti are painted by using batik wax on wood media that has been formed as to be produced. Until now Krebet Tourism Village already has 46 workshops that produce various products for consumers of wooden batik lovers.

Wood becomes the main raw material for handicraft product from Krebet Tourism Village. The wood used

\footnotetext{
* Corresponding author: dwidiyastuti@ugm.ac.id
} 
generally has soft characteristics with bright base color so it easily absorbs water and dye, for example, is wood pule, klepu wood, and sengon wood, while for non-batik product or furniture generally use a harder type of wood with fiber and color typical wood such as teak wood. Each workshop can use more than one type of timber tailored to the product to be produced as well as consumer demand that takes into account the price and quality of the product. Wood for production is generally obtained from suppliers outside the village, both on a regional scale in Bantul (48\%) and other districts (39\%) $[6,7]$. Various types of products using the type of wood used by craftsmen also vary so that wood raw materials cannot be met by simply relying on products from within the village, so it is necessary to bring the wood from other areas.

Table 1. Raw materials and work division of wooden batik workshops.

\begin{tabular}{|l|c|c|}
\hline Characteristics & $\begin{array}{c}\text { Number of } \\
\text { workshops }\end{array}$ & \% \\
\hline Source of Wood & & \\
\hline Local (inner village) & 34 & $(48)$ \\
\hline Regional (inner regency) & 28 & $(39)$ \\
\hline Other region (outside regency) & & \\
\hline Source of wax and dyes & 28 & $(93)$ \\
\hline Inner village & 2 & $(7)$ \\
\hline Outside village & & \\
\hline Water source & 11 & $(41)$ \\
\hline Wells & 13 & $(48)$ \\
\hline Public pipe water & & $(11)$ \\
\hline Wells and public pipe water & & \\
\hline
\end{tabular}

Source : Primary Research Data 2017

Other materials needed for the craft production process are batik candles and dyes. The results showed as many as 28 workshops obtained the material from their own village. If the supply of materials from the village runs out, new craftsmen will buy from the city of Yogyakarta. The process of batik and coloring also requires water in the production process. The water required is considerable, especially at the wax detaching and washing stage. This causes the availability of water becomes very important for the craftsmen. Based on water sources, 27 workshops requiring water for production are 3 workshops that use water from wells, 11 workshops from PDAM, and 13 others use both. The provision of production supporting materials may involve several parties such as Koperasi Sidokaton providing batik waxes and dyes and service providers for water needs such as PDAMs (Public Pipe Water Provider).
Production stage of wooden batik handicraft is generally classified into four parts: (1) initial stage, (2) batik, (3) staining and (4) final stage. The initial stage is the process of making wood shape according to the ordered product. The stage of batik and coloring is done to add batik motif and color to wood that has been formed. After going through the process of batik and coloring, wooden batik craft then washed and dried to dry. In the final stages, wooden batik products will be given ornaments such as hangers or hooks. Broadly speaking, the products produced by workshopsworkshops in Krebet Tourism Village is divided into two, namely wooden and non-batik handicraft products. The most popular products are wooden functional handicraft products such as tissue boxes, trays, to bookmarks. Not only functional wooden batik products, but wooden batik products for souvenirs are also no less attractive by the market. The results showed that as many as 15 workshops with complete production stage produce more types of handicrafts with functional form and souvenirs for the market demand. Other types of handicrafts that interest is wayang (puppet), batik masks, classical masks, furniture products, and other types of art products.

The whole stage of production undertaken to produce wooden batik products is done by the craftsmen either the owner of the workshops or employee workshops. Each stage of production is done in bulk, meaning that the production process of each stage is completed first and then to the next stage which aims to save time and save the compounding of raw materials such as a dye. A number of workers or craftsmen Each gallery is generally varied. A total of 32 workshops in Krebet Tourism Village have a number of craftsmen as many as 1-5 people, 9 workshops with the number of craftsmen 6-10 people, and 4 workshops with crafters more than 10 people. All craftsmen generally work in the workshops starting from 08:00 to 16:00 in workshop. Despite having a workforce or craftsman and the existence of regular working hours, there is the possibility of several stages of work such as batik stage done in the home of each craftsman where there is no provision of working hours. It shows the production process of wooden batik is more flexible compared to other craft.

The production of wooden batik from the production place is directly sold by the craftsmen without going through a special quality control stage. The method of selling wooden batik products is different, generally classified into three, i.e. directly to consumers, through intermediaries, or by both ways. The results showed 41 $\%$ of the workshops sell handicraft products through two ways at once, i.e. directly to consumers and through intermediaries. Sales of products in two ways at once is often done by the workshop that performs a complete production stage that processes raw materials to become finished goods in the form of wooden batik handicrafts. Workshop with a complete process can sell the product directly because it already has a regular consumer or takes advantage of online media. They already have a showroom to put all wooden batik products so that visitors who come to the village tour can directly buy it. 
In addition, they can sell their products through the collectors or deposited in souvenir shops. Sales in two ways, i.e. directly to the consumer or to the collectors can also be done by the workshops with semi-finished production stage or 'putihan'. Direct sales to consumers can be done by the workshops that have the stage of half-finished can be done if consumers do not ask for products that have been batik but only wood products with a certain form that has been mashed or given varnish surface. Workshops that only do the process of batik or workshop non batik generally sells their products through intermediaries.

The amount of production and sales of wooden batik products is also influenced by market demand factor. Market demand for wooden batik products can be illustrated by market demand trends classified into several types: fixed, decreasing, increasing, and fluctuating. The market demand for Krebet batik products in the last one year according to 17 workshops is fixed, according to 13 workshops tends to increase, and 12 workshops declare a downward trend. Market demand trends are basically also influenced by seasonal buying interest. In certain months that have long holidays such as before the holiday, New Year eve and holiday seasons, the trend of product sales tends to increase so that the demand to the workshops also increases. This is because the increasing number of tourists visiting the tourist destination in Yogyakarta Province resulted in increased souvenir products also increased. The declining trend of demand for wooden batik is due to several things: the demand for special products so that only a few workshops are able to fulfill the demand, the completion of the contract with the trading, and other obstacles related to marketing.

Based on the process of making the products from raw materials to finished goods which are channeled at the stage of selling wooden batik products from Krebet Tourism Village, in general there are five parties involved i.e. the providers of raw materials or which can be called the suppliers, craftsmen, collectors or wholesalers, traders or retailers, and end consumers $[7,8]$. Sales of wooden batik products nowadays have started to be done directly by craftsmen to consumers with the online media as a means of promotion and product sales. The description of the production process and the parties involved in the flow of wooden batik products can be described in a value chain scheme of wooden batik products as shown in Figure 1. In general, the value chain that occurs for all types of wooden batik products is the same. Differences may occur in the crafters who directly make the sale of products to consumers with craftsmen who do product sales through the collectors or traders. Differences in the production process by craftsmen can also affect the flow of the value chain although its influence is not significant. The shortest chain value occurs in the type of workshops that produces wooden batik with the complete stage and directly sell the results to the consumer, whereas in the workshops that actually only do marketing, the value chain tends to be longer because they have to cooperate with other craftsmen first.

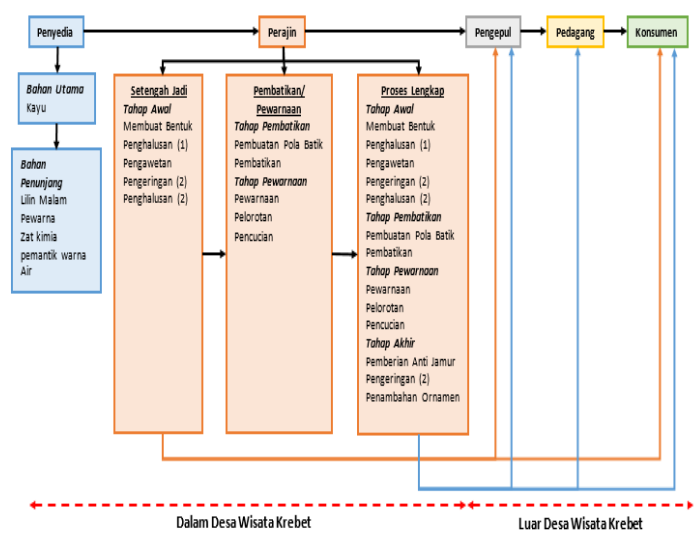

Fig. 1. Value chain of wooden batik commodities. Source: Research Analysis, 2017

\section{Marketing distribution of wooden batik products}

Wooden handicraft product is a superior product produced by the crafters in Krebet Tourism Village. Based on the value chain analysis shown in Figure 1, after going through the production process from raw materials to finished goods, wooden batik handicraft products are ready to be marketed. Product marketing can be done by the workshops directly or through the help of collectors and other traders. Although classified into locally produced craft species in Krebet Tourism Village, the marketing of wooden batik products is recognized not only able to penetrate domestic market but also penetrate foreign market. This can be seen from the scale of marketing distribution that occurs in wooden batik products.

Based on the marketing distribution scale, there are generally 4 classification of distribution scale that occurs in wooden batik products from Krebet Tourism Village. The classification is on the scale of local, regional, national, and international sales. On a local sales scale there are 7 workshops that only sell their products within the Krebet Tourism Village. Sales of products on a local scale generally occurs in the workshops that only do the process of batik or workshops that is relatively young so it does not have many consumers. Workshops who perform batik process generally sell the results through the workshops that have a showroom.

Product sale to the regional scale at least done by 24 workshops in Krebet Tourism Village. The products of 24 workshops are able to be sold within the scope of D.I Yogyakarta Province which includes Bantul, Sleman, Gunungkidul, Kulon Progo, and Yogyakarta. Products sold on a regional scale can be directly up to the end consumer or sold at a souvenir shop located around the tourism area, such as along Malioboro Street, Bringharjo Market, and gift shop like Mirota Batik. Scale distribution of sales of wooden batik products most often done by workshops in Krebet Tourism Village is on a national scale. Sales of products to the national scale has been done by at least 28 workshops $[9,10]$. The scope of marketing entering the national scale is between cities and inter-provinces in Indonesia. Some areas in Indonesia that have become the marketing destination of wooden batik products are Lampung, Medan, Jakarta, Bogor, Bandung, Magelang, Solo, Pekalongan, 
Surabaya, Bali, some areas in Kalimantan Island, to Makassar. Product sales up to the national scale are generally done by craftsmen through the help of collectors or retailers.

Table 2. Scale of product distribution of wooden batik handicraft from Krebet Tourism Village

\begin{tabular}{|c|c|c|}
\hline Selling scale & $\begin{array}{l}\text { Number of } \\
\text { workshops }\end{array}$ & Selling destinations \\
\hline Local & 7 & $\begin{array}{l}\text { Krebet Tourism } \\
\text { Village }\end{array}$ \\
\hline Regional & 24 & $\begin{array}{l}\text { Province of D.I } \\
\text { Yogyakarta. Sleman, } \\
\text { Bantul, Kulon Progo, } \\
\text { Gunungkidul } \\
\text { Regencies, and } \\
\text { Yogyakarta city }\end{array}$ \\
\hline National & 28 & $\begin{array}{l}\text { Indonesia areas. } \\
\text { Lampung, Medan, } \\
\text { Jakarta, Bogor, } \\
\text { Bandung, Magelang, } \\
\text { Solo, Pekalongan, } \\
\text { Surabaya, Bali, } \\
\text { Makassar }\end{array}$ \\
\hline International & 14 & $\begin{array}{l}\text { Other countries. } \\
\text { Singapura, Malaysia, } \\
\text { India, Arab, China, } \\
\text { Russia, Spain, } \\
\text { England, USA, } \\
\text { Australia }\end{array}$ \\
\hline Not sell & 2 & - \\
\hline Not yet operated & 1 & - \\
\hline
\end{tabular}

Source: Research Analysis, 2017

One way to develop a business is to expand the market to national and international levels. Distribution of marketing of wooden batik products from Krebet Tourism Village currently not only penetrate the market up to national scale but also international. Currently, as many as 14 workshops in Krebet Tourism Village have managed to produce wooden batik handicrafts are sold to the international scale. Some countries that have become the marketing distribution destination of wooden batik products are Singapore, Malaysia, India, Arab, China, Russia, Spain, UK, USA, and Australia. Product sales to international scale are made by artisans through intermediaries, especially through trading such as Arbitrage Trading Program (ATP), or through foreign tourists directly. The arrival of foreign tourists to Krebet Tourism Village allows interaction with the craftsmen. This is used by craftsmen to become an opportunity for product marketing to the international scale so as not to rule out the possibility for the craftsmen also have a fixed consumer who comes from various countries.

Based on the estimated turnover of each studio, 32 workshops have a turnover of 1 to 10 million per month, 5 workshops with a turnover of 11-20 million per month, and there are 7 workshops with a turnover of more than 20 million per month. The more product demand, the number of consumers remain, and the more varied the way sales can increase the turnover studio, especially workshops that successfully brought its products penetrate the international market. Expanding the scale of marketing to the international scale tends to be more difficult than the national. At least there must be good product quality stability and the uniqueness and attractiveness of the products offered. The products exported are not only wooden batik masks or functional equipment, but the existing workshops also serve the manufacture of special-shaped craft with wood base material. Reflecting on the product of wooden batik handicrafts produced from Krebet Tourism Village it can be said that the uniqueness and attractiveness contained in wooden batik products can be well received by the market and can compete with other products on an international scale.

Based on the results of value chain analysis of wooden craft products and the description of sales distribution of wooden batik products allows the value of products and high value-added products. Value chain formed by wooden batik products shows the possibility of the possibility of value-added products from craftsmen to collectors, traders, until reaching the final consumer. Value-added products could also occur due to differences in the location of product sales that can reach out of Krebet Tourism Village, especially products that reach the international sales scale when raw materials and product manufacturing process is only done in local to regional scale.

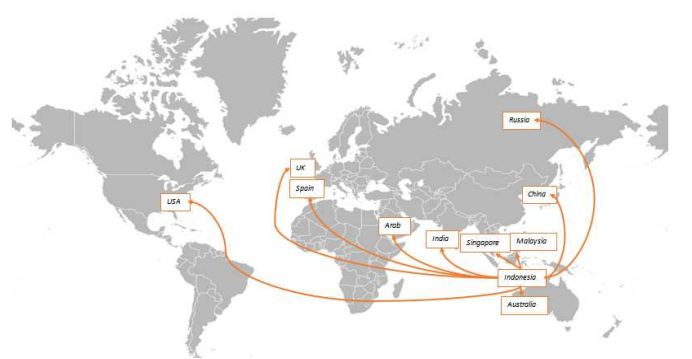

Fig. 2. Flow of wooden batik product distribution in international scale. Source: Research Analysis, 2017

\section{Conclusion}

Value chain analysis of wooden craft products describes the production process and the involved actors are the providers of the main raw materials and supporting materials for the production process, the craftsmen who process raw materials and supporting materials into wooden batik products, distributors who distribute products, traders who sell products, and end consumers as users of wooden batik products from Krebet Tourism Village.

Based on the whole process of value chain and distribution of product marketing, all raw materials and production process of wooden batik is mostly done in Krebet Tourism Village and still enter into one region of Bantul Regency, but the handicraft product has been able to penetrate the international market. 
Acknowledgments and appreciation are given to all parties related to this research, especially all craftsmen in Krebet Tourism Village and all research teams who have assisted in conducting this research.

\section{References}

1. Damanik, Janianton dan Frans Teguh. Manajemen Destinasi Pariwisata: Sebuah Pengantar Ringkas. Yogyakarta: Kepel Press (2012)

2. Dewi, Ike Janita Implementasi dan Implikasi Kelembagaan. Pemasaran Parwisata yang Bertanggungjawab (Responsible Tourism Marketing). Kementrian Kebudayaan dan Pariwisata Republik Indonesia (2011)

3. Inskeep, E. Tourism Planning, and Integrated and Sustainable Development Approach. New York: Van Nostrand Reinhold (1991)

4. Kaplinsky, R dan M. Moris. A Handbook for Value Chain Research. International Development Research Center, Ottawa, Canada (2001)

5. Kurniawati, Dyah Yuni Kerajinan Batik Kayu Krebet. Gelar. 12 (1) (2014)

6. Layalie, Tiesa Sa'adatul dan Siti Fadjarajani. Kerajinan Batik Kayu sebagai Ciri Khas Desa Wisata Krebet di Dusun Krebet Desa Sendangsari Kecamatan Pajangan Kabupaten Bantul. Universitas Siliwangi (unpublished)

7. Nuryanti, W. Heritage, Tourism and Local Communities. Yogyakarta: UGM Press (1999)

8. Pearce, D. Tourism A Community Approach. 2nd: Harlow Longman (1995)

9. Rosales, Rina Maria, dkk. Value Chain Analysis and SmallScale Fisheries Management. Marine Policy, 83, 11-21 (2017)

10. Wearing, S.L. and Donald, Mc. The Development of Community Based Tourism: Re-Thinking the Relationship between Tour Operators and Development Agents as Intermediaries in Rural and Isolated Area Communities. Journal of Sustainable Tourism (2001)

11. Widiyastuti, Dyah, dkk. Pengembangan Fasilitas dan Infrastruktur dalam Pengelolaan Limbah Kerajinan Batik Kayu di Desa Wisata Krebet dan Desa Wisata Bobung. Laporan Akhir Penelitian. Universitas Gadjah Mada (2017) 